\title{
Preparation and characterization of a bioactive glass/agarose/gelatin nanocomposite scaffold for bone engineering
}

Manar M. Ahmed a, A. M. Ibrahim, Bothaina M. Abd El-Hady ${ }^{\text {a }, ~ A s h r a f ~ F . ~ A l i ~}{ }^{\mathrm{c}}$, Abeer M. El-kady ${ }^{\mathrm{a}}$

${ }^{a}$ Biomaterials Department, National Research Center, 33 El-Behooth St., Dokki, Giza, Egypt

${ }^{\mathrm{b}}$ Physics Departement, University Collage of Women (Arts, Science, and Education), Ain-

Shams University

'Inorganic Chemistry Department, National Research Center, 33 El-Bohooth St., Dokki

12622, Cairo, Egypt

\begin{abstract}
A bioactive glass/agarose/gelatin nanocomposite scaffold was prepared for bone engineering application. The scaffold was characterized by Scaning Electron Microscopy (SEM), Fourier infrared spectra (FTIR), andThermogravimetric Aanalysis(TGA). SEM micrographs showed that the scaffold had a wellinterconnected macroporous structure. TGA indicated that the glass content in the scaffold was $57.12 \%$ which is close to the predecided one $(60 \mathrm{wt} \%)$. The porosity percentage of the scaffold was measured by mercury porosimetry which showed that the scaffold has high porosity percentage $(71.30 \%)$. In vitro bioactivity evaluation was carried out by immersion of the scaffold in simulated body fluid (SBF) for 2 and 4 weeks. Results showed that the scaffold was able to induce an apatite layer on its surface as verified by SEM, FTIR and Thin Film X-ray (TXRD).
\end{abstract}

Key Words: Biocomposites ,agarose and gelatin ,biodegradation,bone treatment.

\section{Introduction}

A bioactive material elicits a specific biological response at the interface of the material, which results in the formation of a bond between the tissue and the material (Hench et al., 1996). The basis of the bone-bonding property of bioactive glasses is the chemical reactivity of the glass in the presence of body fluids. The surface reactions lead to the formation of a hydroxyapatite apatite layer and, as a result of this sequence of reactions, bonding of implant to tissue occurs (Hench et al., 1991) .The original bioactive glasses were prepared through melting of related oxide precursors at a relatively high temperature. The most popular bioactive glass was the 45S5 Bioglass $\left(45 \% \mathrm{SiO}_{2}, 24.4 \% \mathrm{Na}_{2} \mathrm{O}, 24.5 \% \mathrm{CaO}\right.$ and $\left.6 \% \mathrm{P}_{2} \mathrm{O}_{5} \mathrm{wt} \%\right)$. It has been used in several clinical studies (Shapoff et al., 1997). However, increasing the weight of $\mathrm{SiO}_{2}$ in this composition above $60 \%$ resulted in the loss of its in vitro bioactivity and its ability to regenerated bone tissue in vivo (Hench et al., 1991). Advances in solgel processing technology have allowed the fabrication of bioactive gel glasses with a much wider range of $\mathrm{SiO}_{2}$ content and variable levels of $\mathrm{CaO}$ and $\mathrm{P}_{2} \mathrm{O}_{5}$ (Zhong et al., 2000 \&Saravanapavan et al., 2001).

\section{Corresponding author: dr_manarmostafa@yahoo.com}


Those bioactive sol-gel glasses have a higher bioactivity and, therefore, more rapid bone bonding, improved purity and homogeneity, as well as enhanced degradability (Greenspan et al., 1998). Previously, a bioactive glass was used to improve the mechanical properties of several polymeric scaffolds (J.A. Roether et al., 200.2 and Tamjid E. et al., 2011).

Reducing the particle size of materials to the nano-size was shown to improve their biological properties and their grain size was found to influence their ability to promote bone growth (Balasunda et al., 2006, Zhang et al., 2009 \& Webster et al., 2001). Several studies provided significant evidence that ceramics, metals, polymers and composites with nanometer grain sizes selectively enhance the osteoblast function, leading to more bone growth than materials with a micrometer grain size (Webster et al., 2005, Webste et al., 2004, Chiang et al., 2009 and $\mathrm{Li}$ J, et al., 2009). Therefore, the first objective of the present study was to engineer bioactive glass nanoparticles belonging to the system $\left(\mathrm{SiO}_{2}-\mathrm{CaO}\right)$. However, bone regeneration is mainly required in the case of medium to large defects when the bone selfregeneration processes are not enough to heal the defect. In these cases, the bioactive materials cannot be implanted as powder or granulates. To solve this problem, bioactive glass nanoparticles will be blended with agarose and gelatin to produce biocomposites suitable for large bone defect regeneration.

Agarose is a natural polysaccharide obtained from red algae, and has been extensively used in food, cosmetics, and pharmaceutical industries (MarinhoSoriano E. et al., 2003 and Tang S. et al., 2007).Agarose is a biocompatible and biodegradable hydrogel which acts as a gelling agent leading to strong gels and fast room-temperature polymerization. It exhibits macromolecular properties similar to the extracellular matrix and allows enough diffusion and transport of oxygen, essential nutrients, and secretary products across its network (Jen A.C. et al., 1996 and Drury J. L. et al., 2003). Recently, agarose-based scaffolds have been investigated for bone regeneration (Puértolas J.A. et al., 2011 and Sánchez-Salcedo S. et al., 2008). One of the most attractive properties of agarose is that its stiffness can be altered, allowing for tuning of the mechanical and degradation properties of the scaffolds. However, the major drawbacks of agarose are the low cell adhesiveness and cell proliferation (Gruber, et al., 1997). On the other hand, gelatin is a thermally denatured form of collagen that promotes cell adhesion and migration. It is also biocompatible and biodegradable (Wiseman et al., 1998). Gelatin was used in different biomedical applications such as tissue-engineering scaffolds (Mathew Peter et al., 2010, Huang Y. et al., 2005, William B. Hillig et al., 2008, Hye-Won Kang et al., 1999 and Martínez-Vázquez F.J. et al., 2015). Therefore, in this work, agarose will be blended with gelatin to improve its biological properties and its ability to support cell adhesion, migration and proliferation. Moreover, the addition of bioactive glass nanoparticles to those blends is expected to improve their bioactivity and mechanical properties. 


\section{Materials and Methods}

\subsection{Materials}

Tetraethyl orthosilicate (TEOS), calcium nitrate tetrahydrate $\mathrm{Ca}\left(\mathrm{NO}_{3}\right)_{2} \cdot 4 \mathrm{H}_{2} \mathrm{O}$, and triethyl phosphate (TEP) was all $\geq 98 \%$ and purchased from Fluka (Buchs, Switzerland), ammonia solution was $33 \%$, and nitric acid was $68 \%$, from Merck, USA. Both nitric acid and ammonia solutions were used with concentration up to 2.0M. For the polymer phase, we used agarose and gelatin.

\subsection{Sol-gel synthesis of silverdoped bioactive glass nanoparticles}

Bioactive glass nanoparticles with the following composition $\left(67 \mathrm{SiO}_{2}-33 \mathrm{CaO}\right)$ were prepared by a modified sol-gel method (El-Kady A. M., et al., 2012). Initially, tetraethyl orthosilicate, distilled water, and $2 \mathrm{M}$ nitric acid (as a hydrolysis catalyst) were successively mixed in ethanol and the mixture was allowed to react for 60 minutes under continueous magnetic stirring for the acid-hydrolysis of TEOS. The appropriate amount of $\mathrm{Ca}\left(\mathrm{NO}_{3}\right)_{2} \cdot 4 \mathrm{H}_{2} \mathrm{O}$ was then added and stirring was continued for 30 minutes allowing the reagents to react completely.. The mixture was then moved into a conventional ultrasonic bath (working at a frequency of $50-60 \mathrm{kHz}, 100 / 200$ $\mathrm{W}$ ), and $2 \mathrm{M}$ ammonia solution (a gelation catalyst) was dropped into the mixture while vigorously agitated with a mechanical stirrer.

Gelatin of the mixture took place in a few minutes. The combination of both ultrasonic vibration and mechanical agitation of the mixture during gelation was conducted to prevent the formation of a bulk gel. Finally, the prepared gels were dried at $75{ }^{\circ} \mathrm{C}$ for 2 days in a drying oven. According to the results obtained from the thermal analysis of the dry gels, which showed no further weight losses above 700 ${ }^{\circ} \mathrm{C}$, the gels were stabilized by a heat treatment at a constant heating rate of $3{ }^{\circ} \mathrm{C} / \mathrm{min}$ up to $700^{\circ} \mathrm{C}$.

\subsection{Preparation of nanocomposite scaffolds}

Nanocomposite scaffold based on gelatine and agarose was prepared using the freeze extraction method. Bioactive glass nanoparticles were used as fillers. Briefly, $0.2 \mathrm{~g}$ of agarose and $0.2 \mathrm{~g}$ of gelatin were disolved separately in $10 \mathrm{ml}$ of distilled water at 90 and $45{ }^{\circ} \mathrm{C}$, respectively. Bioactive glass nanoparticles were added first to gelatin solution and well-mixed at $45{ }^{\circ} \mathrm{C}$. Then, the prepared agarose solution was added to the glass-gelatin mixture and well mixed. The mixture was poured into a Teflon mold with $10 \mathrm{~mm}$ diameter and $2 \mathrm{~mm}$ height. The mold containing the mixture was kept at $-20{ }^{\circ} \mathrm{C}$. The frozen mixture was removed from mold and immeresed into ethanol solution at $-20{ }^{\circ} \mathrm{C}$ to extract water molecules leaving behined a porous scaffold. Thereafter, the porous scaffold was removed from ethonol solution, washed with distilled water several times and left to dry. The glass content in the scaffold was $60 \mathrm{wt} \%$ as calculated according to the following equation.

$$
\text { Glass content }(\text { wt } \%)=\left[\mathrm{W}_{\mathrm{g}} /\left(\mathrm{W}_{\mathrm{g}}+\mathrm{W}_{\mathrm{p}}\right)\right] \times 100 \%
$$

Where $\mathrm{W}_{\mathrm{g}}$ and $\mathrm{W}_{\mathrm{p}}$ are the weights of the glass and the polymers components, respectively. 


\subsection{Characterization}

\subsubsection{FTIR analysis}

The infrared spectra of the prepared scaffolds were obtained using a Fourier transform infrared spectrophotometer (FT-IR) (model FT/IR- 6100 type A). The spectra were recorded in a wave number range of $400-4000 \mathrm{~cm}^{-1}$.

\subsubsection{Thermal analysis}

Thermogravimetric Analysis (TGA) of the prepared composite was carried out. Scans were performed in air in a temperature range of $50-1000{ }^{\circ} \mathrm{C}$ for the composite scaffold at a rate of $10{ }^{\circ} \mathrm{C} / \mathrm{min}$ using aluminum oxide powder as a reference.

\subsubsection{SEM analysis}

The morphology and the porous structure of the nanocomposite scaffold, as well as their elemental composition, were analyzed with Scanning Electron Microscopy coupled with Energy-Dispersive Spectroscopy, SEM/EDXA (JEOL JXA-840A, Electron probe micro-analyzer, Japan) at $15 \mathrm{kv}$. The scaffolds were cut with a razor blade and were then coated with carbon before examination.

\subsubsection{Measurement of porosity $\%$ of the scaffolds}

The porosity percentage of the nanocomposite scaffolds was measured using the mercury intrusion porosimetry technique. (19321, Micrometric, USA)

\subsubsection{In- vitro bioactivity evaluation}

The in vitro bioactivity of the scaffold was assessed by investigating the formation of the apatite layer on their surfaces during immersion in the simulated body fluid (SBF) under normal physiological conditions as proposed by others (Saboori et al., 2009). Scaffolds were prepared and soaked in SBF that was maintained at $37{ }^{\circ} \mathrm{C}$ for two weeks. The SBF had a composition and an ionic concentration almost equal to human plasma. The inorganic ion concentrations in SBF were: $\mathrm{Na}^{+} 142.0 \mathrm{mM}, \mathrm{K}^{+} 5.0 \mathrm{mM}, \mathrm{Ca}^{2+} 2.5 \mathrm{mM}, \mathrm{Mg}^{2+} 1.5 \mathrm{mM}, \mathrm{Cl}^{-} 148.0 \mathrm{mM}$, $\mathrm{HCO}_{3}{ }^{-} 4.2 \mathrm{mM}, \mathrm{HPO}_{4}{ }^{2-} 1.0 \mathrm{mM}$ and $\mathrm{SO}_{4}{ }^{2-} 0.5 \mathrm{mM}$. The solution was buffered at $\mathrm{pH}$ 7.4 with tris(hydroxymethyl) aminomethane and $1 \mathrm{M} \mathrm{HCl}$ at $37{ }^{\circ} \mathrm{C}$ (Kokubo et al., 2000). The formation and growth of an apatite layer on the surface of the scaffolds was verified by scanning electron microscopy coupled with energy-dispersive spectroscopy, SEM (JEOL JXA-840A, Electron probe micro-analyzer, Japan), thinfilm X-ray analysis (TF-XRD) (Panalytical, X'Pert Pro, The Netherlands), employing $\mathrm{Ni}$-filtered $\mathrm{Cu} \mathrm{K \alpha}$ irradiation at $45 \mathrm{Kv}$ and $40 \mathrm{~mA}$, and Fourier-Transform Infrared spectra, (FT-IR) (6100 type A machine) in the range of $400-4000 \mathrm{~cm}^{-1}$. 


\section{Results and Discussion}

\subsection{Characterization}

\subsubsection{FTIR analysis}

Figure(1) shows the FTIR spectra of bioactive glass/agarose/gelatin nanocomposite scaffold before soaking in SBF. A peak was observed in the range of $3600-2986 \mathrm{~cm}^{1}$, which was assigned to the O-H singles coupled with stretching vibrations for agarose. A small peak was noticed at $2924 \mathrm{~cm}^{-1}$ ascribing to $\mathrm{CH}_{2}$ agarose mode. Another peak was observed at about $1461 \mathrm{~cm}^{-1}$, and was attributed to $\mathrm{C}-\mathrm{C}$ bonding vibration for the agarose. Also, a peak was observed in the range of $1077-1154 \mathrm{~cm}^{-1}$ which was assigned to the C-O-C stretching vibration glycosidic linkage for the agarose as shown in Fig.(1). Moreover, the spectrum showed the characteristic peaks of gelatin, the peak noticed at $1655 \mathrm{~cm}^{-1}$ was ascribed to the characteristic peptide linkage of $\mathrm{C}=\mathrm{O}$ stretching vibration from amid $\mathrm{I}$. The peak at $1542 \mathrm{~cm}^{-1}$ was also attributed to gelatin.

The FTIR spectra of composite scaffolds showed all the characteristic peaks for bioactive glass as reported elsewhere (Yong, et al., 2008). These are the band located in the range of $1000-1200 \mathrm{~cm}^{-1}$ which corresponds to $\mathrm{Si}-\mathrm{O}-\mathrm{Si}$ asymmetric stretching vibration whereas the band observed in the range of $725-800 \mathrm{~cm}^{-1}$ is attributed to the $\mathrm{Si}-\mathrm{O}-\mathrm{Si}$ symmetric stretching vibration. Another peak, seen at $878 \mathrm{~cm}^{-1}$, was assigned to the $\mathrm{Si}^{-} \mathrm{O}^{-}$with two non- bridging oxygen per $\mathrm{SiO}_{4}$ tetrahedron.

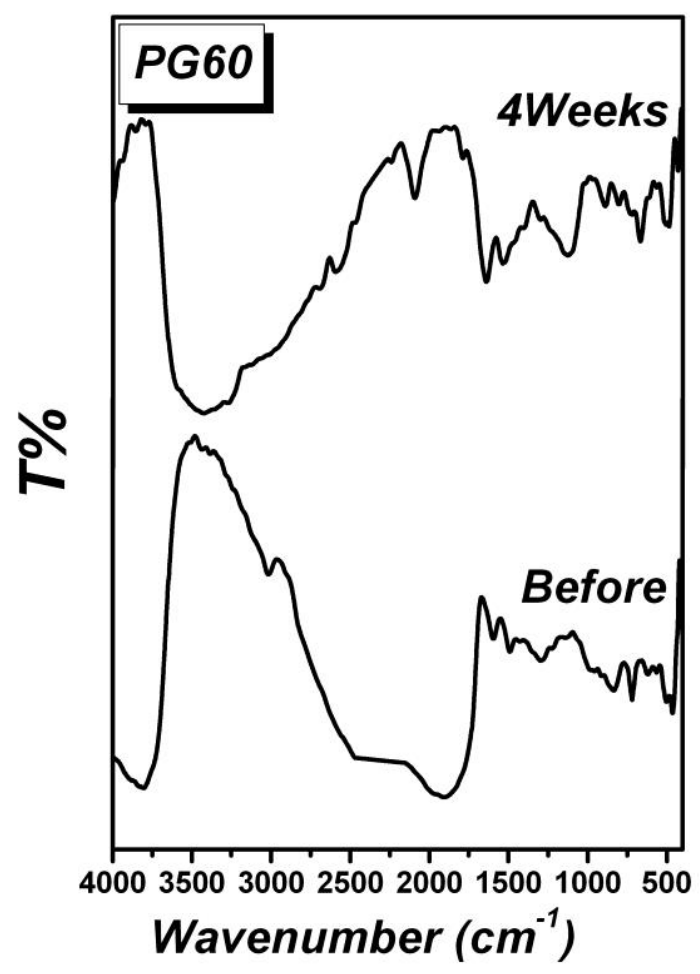

Fig. (1): The FTIR spectra of Bioactive glass/agarose/gelatin nanocomposite scaffold before and after soaking in SBF. 


\subsubsection{Thermal analysis}

The thermogravimetric analysis, (TGA), of the composite scaffolds is shown in Fig. (2). The total weight loss recorded for nanocomposite was $42.88 \%$. This weight loss was attributed to decomposition and burning of polymers leaving behind bioactive glass particles. Based on TGA data, the glass content is $57.12 \%$, which is close to the predicated glass content $(60 \mathrm{wt} \%)$.

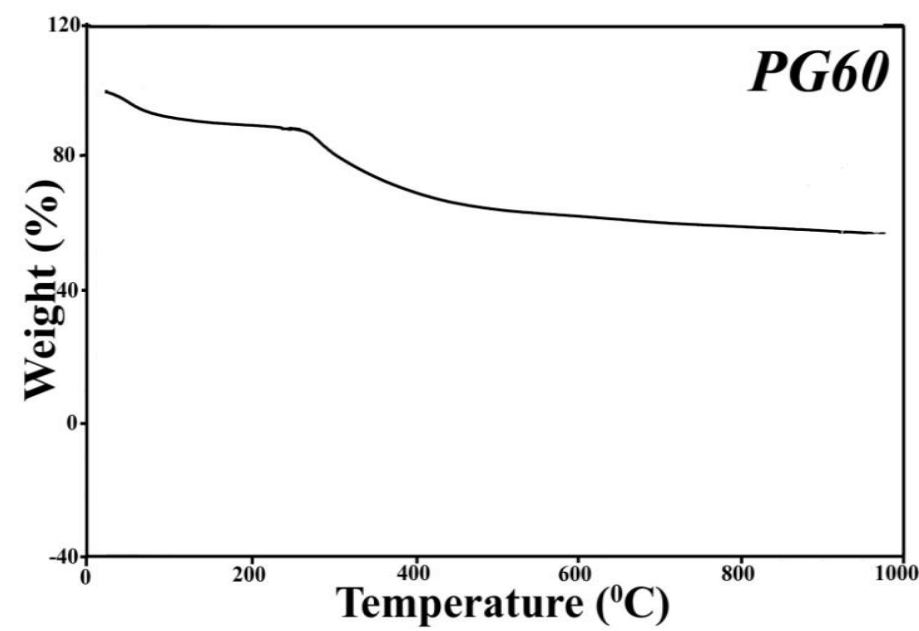

Fig. (2): The thermogravimetric analysis (TGA) of the composite scaffolds PG60.

\subsubsection{SEM analysis}

Figure. (3) The SEM micrographs of the nanocomposite scaffolds where their interconnected and microporous structure can be clearly observed. The presence of bioactive glass particles as a filler in nanocomposite scaffold was confirmed from the EDX analysis plot (Fig. 4), which showed silica and calcium peaks of glass filler.
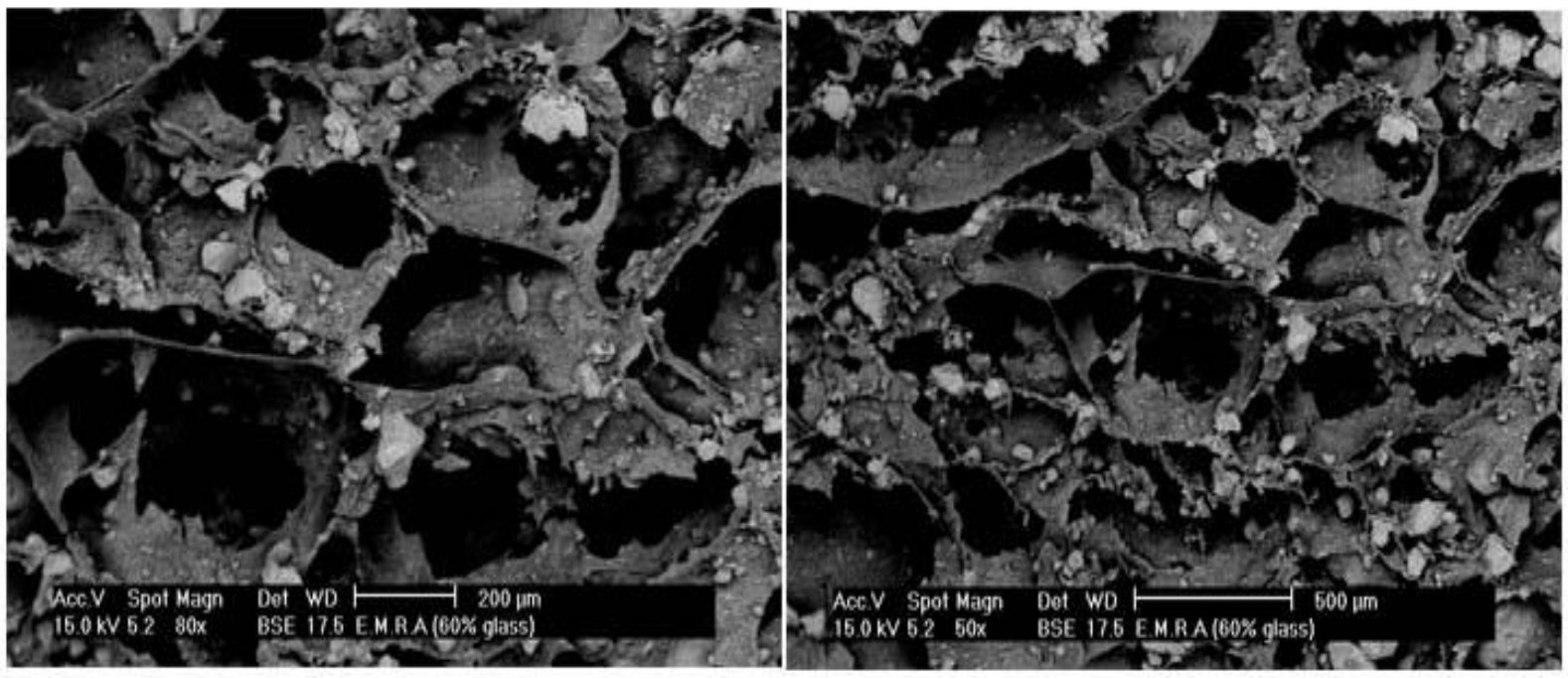

Fig (3): The SEM micrographs of the nanocomposite scaffolds PG60 where their interconnected porous structure can be clearly observed. 


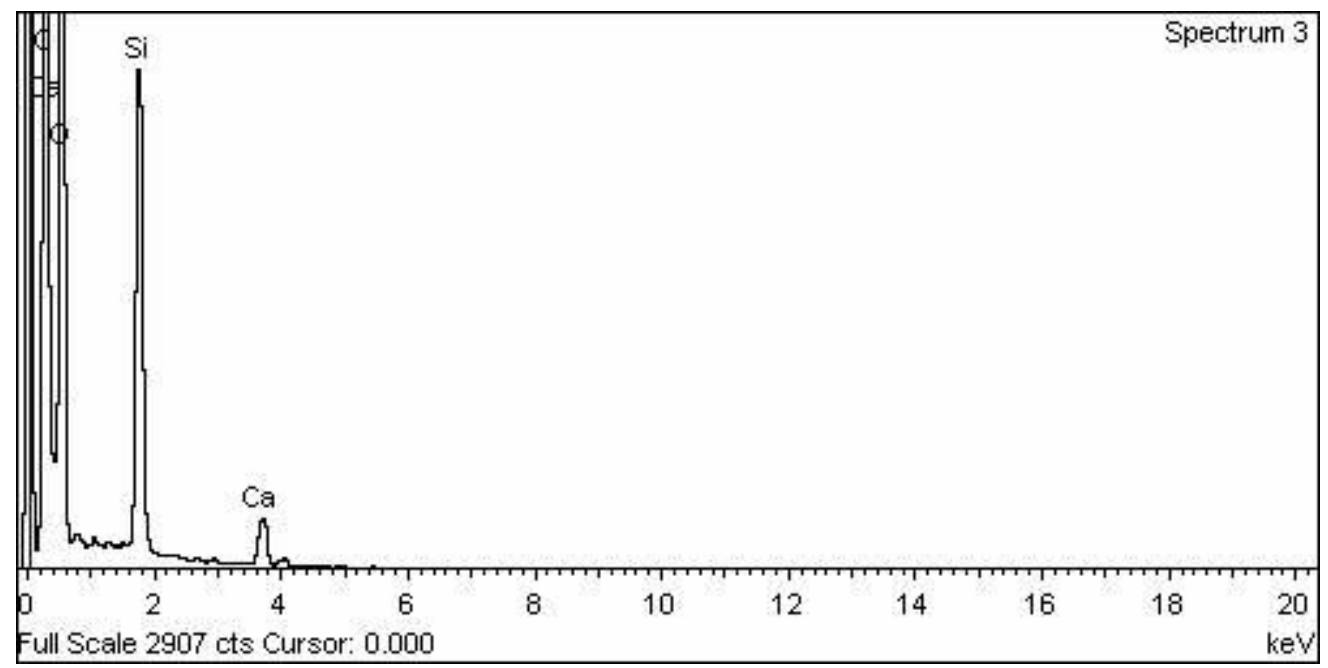

Figure (4): The EDX analysis plot for nanocomposite scaffold.

\subsubsection{Measurement of porosity percentage of the nanocomposite scaffold}

The porosity percentage of the scaffold was measured by the mercury intrusion porosimetry technique. It had high porosity percentage $(71.30 \%)$. The total pore volume, total surface area and average pore diameter were $0.7974 \mathrm{ml} / \mathrm{g}, 131.944 \mathrm{~m}^{2} / \mathrm{g}$ and $24.2 \mu \mathrm{m}$, respectively.

\subsection{In vitro bioactivity evaluation}

\subsubsection{SEM analysis}

Figure.(5) shows the SEM micrographs of the surfaces of the nanocomposite scaffolds after immersion in the simulated body fluid (SBF) for two weeks and one month. On the other hand, a very thick layer consisting of spherical particles was completely covering the surfaces of nanocomposite scaffolds PG60 that is a hydroxyapatite. 


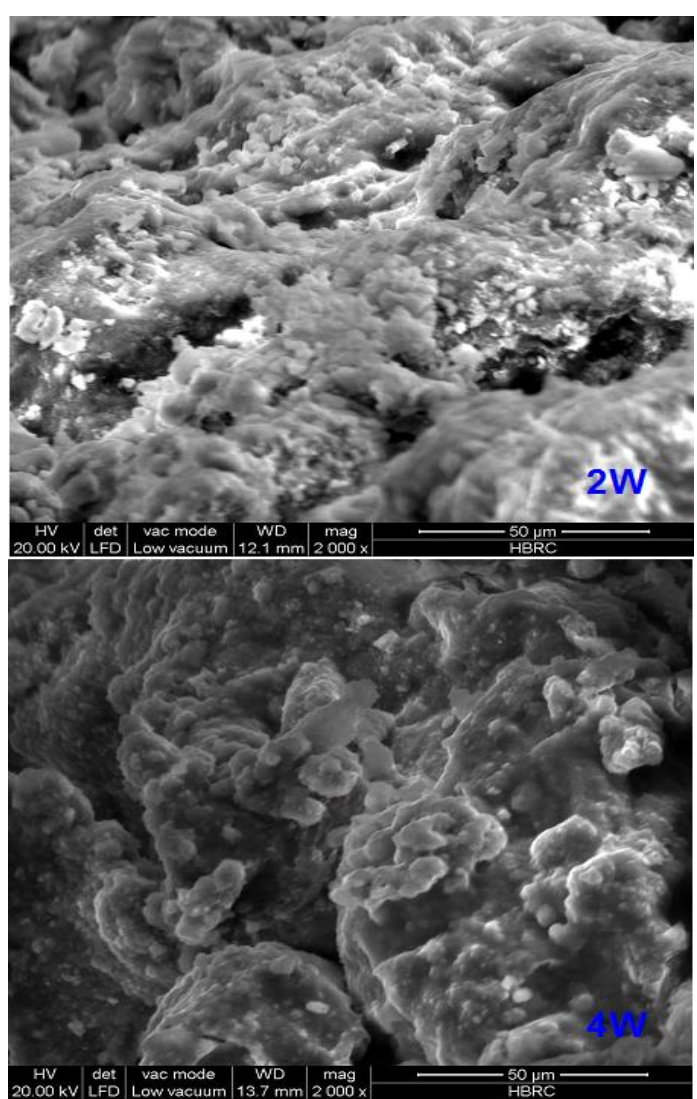

Fig(5) : SEM micrographs of the surface morphology of nanocomposite scaffold after immersion in the SBF for 2 and 4 weeks.

\subsubsection{Thin Film X-rays}

The thin-film X-ray analysis (TF-XRD) was used to confirm that spherical particles formed on the surface of nanocomposite were hydroxyapatite. Fig. (6) shows the TF-XRD patterns of the surface of nanocomposite scaffold after immersion in SBF for 4 weeks.

The peaks at d-spacing values of $2.82 \AA, 3.78 \AA$ and $3.73 \AA$ were seen in the pattern of those scaffold (matched with ICSD card number 82-1944). The appearance of other peaks with d-spacing values of $3.44 \AA$, $3.17 \AA$, 3.09, $2.63 \AA, 2.04 \AA, 1.94 \AA$, $1.72 \AA, 1.61,1.68 \AA$ and $1.45 \AA$ (matched with ICSD card number 82-1244) was also noticed confirming the formation of an apatite layer on each of those samples. 


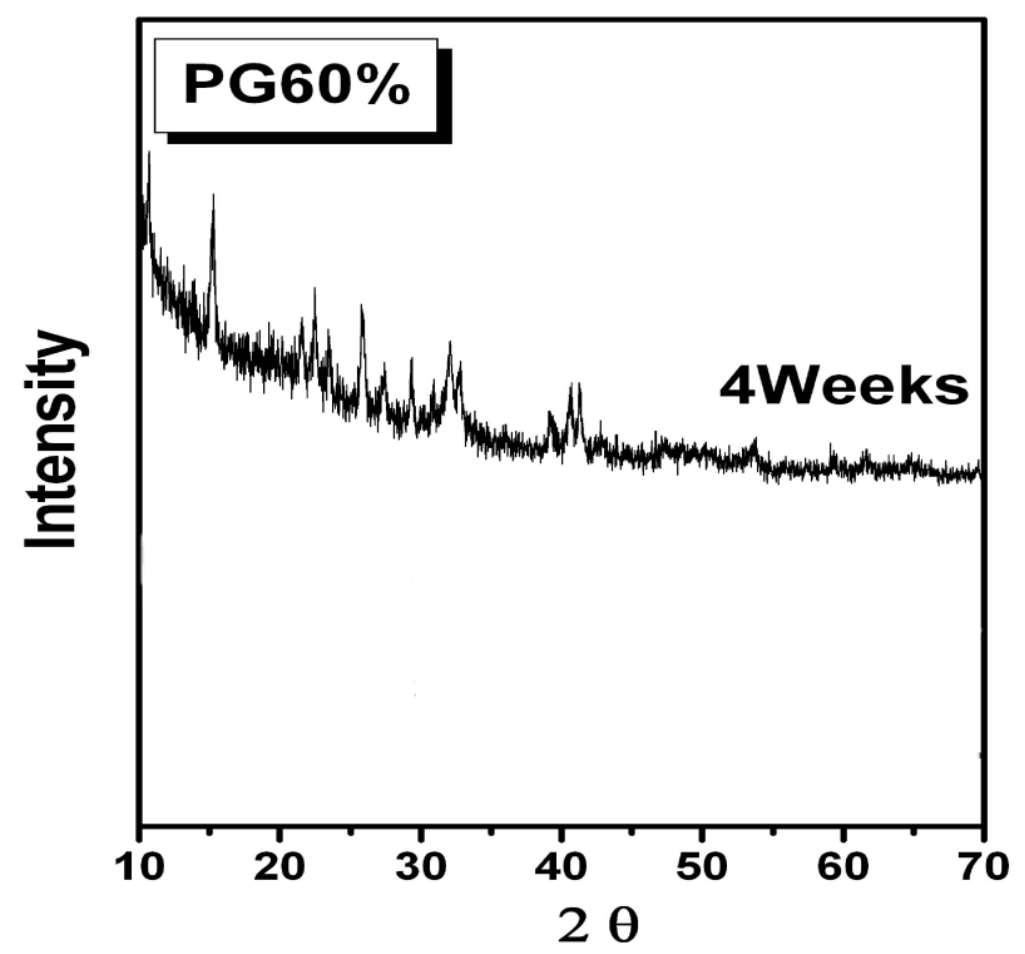

Fig(6): TF-XRD patterns of the surface of a nanocomposite scaffold after immersion in SBF for 4 weeks.

\subsubsection{FTIR analysis:}

Figure (1) shows the FTIR spectrum of nanocomposite scaffold after immersion in SBF for a month. The spectrum showed the bands of the of carbonate hydroxyapatite where the bands at $1035,955,601,568 \mathrm{~cm}^{-1}$, could be assigned to the phosphate group, and those at 1487,1419 and $871 \mathrm{~cm}^{-1}$ to the carbonate. The 601 and $568 \mathrm{~cm}^{-1}$ doublet is a characteristic feature of phosphate in crystalline phases. (Izquierdo-Barba I,et al., 1999).

\section{Discussion}

Compared to the melt-quenching technique, sol-gel processing produces glasses at low processing temperatures with a higher homogeneity, purity and bioactivity (Zhong et al., 2000). Moreover, the prepared glasses have porous structures with a high specific surface area. In most sol-gel techniques to synthesize silicate glass, sols were formed by the hydrolysis of low molecular weight alkoxysilanes, such as tetraethoxysilane (TEOS) using water in presence of a catalyst. The hydrolysis reaction replaced alkoxide groups with hydroxyl groups. Siloxane bonds $(\mathrm{Si}-\mathrm{O}-\mathrm{Si}$ ) were then formed during a subsequent condensation. Further condensation leads to gelation which, after drying, forms a dry gel called xerogel. Alcohol and water are byproducts of the condensation reaction which evaporate during drying (Hench et al., 
1990). The whole preparation process can generally be described by the following reactions:

$$
\begin{gathered}
\mathrm{Si}\left(\mathrm{OC}_{2} \mathrm{H}_{5}\right)_{4}+\mathrm{nH}_{2} \mathrm{O} \rightarrow \mathrm{Si}\left(\mathrm{OC}_{2} \mathrm{H}_{5}\right)_{4-\mathrm{n}}(\mathrm{OH})_{\mathrm{n}}+\mathrm{nC}_{2} \mathrm{H}_{5} \mathrm{OH} \text { (hydrolysis) [1] } \\
-\mathrm{SiOH}+\mathrm{C}_{2} \mathrm{H}_{5} \mathrm{O}-\mathrm{Si} \rightarrow-\mathrm{Si}-\mathrm{O}-\mathrm{Si}-+\mathrm{C}_{2} \mathrm{H}_{5} \mathrm{OH} \text { (alcohol condensation) [2] } \\
\quad-\mathrm{Si}-\mathrm{OH}+\mathrm{OH}--\mathrm{Si}-\rightarrow-\mathrm{Si}-\mathrm{O}-\mathrm{Si}-+\mathrm{H}_{2} \mathrm{O} \text { (water condensation) [3] }
\end{gathered}
$$

The introduction of calcium ions to the silica network was expressed by the following reaction:

$$
\mathrm{Si}-\mathrm{O}---\mathrm{Ca}---\mathrm{O}-\mathrm{Si}+2 \mathrm{H}^{+} \leftrightarrow \mathrm{Ca}^{2+}+2[\mathrm{Si}-\mathrm{OH}][4]
$$

Calcium ion $\left(\mathrm{Ca}^{2+}\right)$ acts as a network modifier, and one calcium ion will be present for each pair of non-bridging oxygen atoms in the silica network (Kim et al., 2008).

It is well known that the final size of sol-gel derived powders depends greatly on the type of the catalyst used, which influences the $\mathrm{pH}$ of the solution and alters the relative rates of hydrolysis and condensation reactions (Brinke et al., 1990). Preparation of bioactive glasses by the traditional sol-gel process was reported by others (Saravanapavan et al., 2001). One-step acid catalysis, needs a long gelation time, which allows the aggregation and growth of colloidal particles in the solution, leading to a final product with a particle size greater than $1 \mathrm{~mm}$ (Sepulveda et al., 2001). However, in this study, the traditional sol-gel process was modified by the addition of ammonia solution. Therefore, two-step acid-base catalysis was followed. The addition of ammonia solution as a second catalyst to a sol, that is initially catalyzed by nitric acid, was found to increase the rate of condensation reactions and reduce the gelation time to several minutes rather than days as in the case of the traditional sol-gel process. This is due to the fact that the condensation rate is proportional to $\left[\mathrm{OH}^{-}\right]$above the isoelectric point (Brinker et al.,1990). In this study, excess $2 \mathrm{M}$ ammonia was used for gelation and this provided an environment of $\mathrm{pH}$ much higher than the isoelectric point of silica (Brinke et al.,1990). Gelation time could thus be significantly decreased. Fast gelation of sol and the application of a moderate ultrasonic dispersion combined with mechanical agitation, as well as the addition of ethanol as a dispersant in our study seem to lead to smaller grains of a regular spherical shape, if compared with the normal sol-gel conversion using only the acid hydrolysis route. Therefore, glass particles less than $100 \mathrm{~nm}$ were successfully prepared using two-step acid-base catalysis in this study.

A highly porous glass/agarose/gelatin nanocomposite scaffold with well interconnected structures was successively prepared in this study by the freeze-extraction method. This method was carried out by freezing the bioactive glass/agarose/gelatin mixture below the solvent (water) freezing point at $-20{ }^{\circ} \mathrm{C}$, to induce the phase separation between polymers and solvent, and to create a polymer rich phase that 
surrounds the water crystals. The Final stage was immersion of the frozen polymers mixture in ethanol bath at the same freezing temperature $\left(-20^{\circ} \mathrm{C}\right)$. This is carried out to extract the water by ethanol (Ethanol is a non solvent for agrose or gelatine) leading to a well inter-connected porous structure,

A key feature of bioactive materials is their ability to form a hydroxyapatite layer on their surfaces in vivo and in vitro (Xin et al., 2005, Kokubo et al., 2006). The novel nanocomposite scaffold was able to induce an apatite layer on its surface during the immersion in the simulated body fluid (SBF) as verified by SEM, TF-XRD and FTIR demonstrating its potential application in bone engineering. The formation of the hydroxyapatite layer on the surface of nanocomposite scaffolds that was immersed in SBF were attributed to the presence of glass nanoparticles as fillers in nanocomposite scaffold.

The role of glass nanoparticles in a hydroxyapatite layer formation could be explained by a complex 5-stage process as proposed by others (Hench et al.,et al., 1990 , Shapoff et al., 1997 , Zhong et al., 2000, and Saravanapavan et al., 2001). These are:

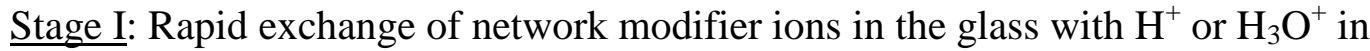
solution.

$$
[\mathrm{SiO}]_{2} \mathrm{Ca}^{2+}+2 \mathrm{H}^{+}+\mathrm{OH}^{-} \leftrightarrow 2 \mathrm{Si}-\mathrm{OH}+\mathrm{Ca}^{2+}+\mathrm{OH}^{-}[6]
$$

Stage II: Loss of soluble silica as $\mathrm{Si}(\mathrm{OH})_{4}$ by breaking of Si-O-Si bridges and subsequent formation of surface silanol $(\mathrm{Si}-\mathrm{OH})$ groups in the process.

$$
2(\mathrm{Si}-\mathrm{O}-\mathrm{Si})+2(\mathrm{OH}) \rightarrow 2(\mathrm{Si}-\mathrm{OH})+2(\mathrm{HO}-\mathrm{Si})[7]
$$

Stage III: Condensation and repolymerization of surface silanols to form a $\mathrm{SiO}_{2-}$ rich surface layer.

$$
2(\mathrm{Si}-\mathrm{OH})+2(\mathrm{HO}-\mathrm{Si}) \rightarrow-\mathrm{Si}-\mathrm{O}-\mathrm{Si}-\mathrm{O}-\mathrm{Si}-\mathrm{O}-\mathrm{Si}-\mathrm{O}-[8]
$$

Stage IV: Migration of $\mathrm{Ca}^{2+}$ and $\mathrm{PO}_{4}{ }^{3-}$ to the surface through the silica-rich layer and formation of an amorphous $\mathrm{Ca}-\mathrm{P}$ rich layer on the surface of the glass by incorporating soluble calcium and phosphate from the solution.

Stage V: Incorporation of $\mathrm{OH}^{-}, \mathrm{CO}_{3}{ }^{2-}$ from the solution and subsequent crystallization of the Ca-P layer to form hydroxyapatite.

Also, the precepitation of hydroxyapatite layer on the surace of nanocomposite scaffold was due to the formation of ester bond as a result of gelatin and agarose interaction. Agarose is a polysaccharide having numerous $\mathrm{OH}$ groups at $\mathrm{pH}$ 7.5. Gelatin is a polyampholyte with amine and carboxyl functional groups. Gelatin A is positively charged in aqueous solution due to protonation of amino groups $\left(\mathrm{NH}_{3}{ }^{+}\right)$ while Gelatin B is negatively charged due to deprotonation of carboxyl groups $\left(\mathrm{COO}^{-}\right.$ ). In this study we used gelatin $B$ in the fabrication of nanocomposite scaffold and hence, $\mathrm{COOH}$ groups of gelatin $\mathrm{B}$ interacted with $\mathrm{OH}$ groups of Agarose forming 
covalent ester bonds $\left(\mathrm{COO}^{-}\right)$with removal of water. Those ester bonds could attract positive calcium ions from the solution allowing their precipitations on the surface of nanocomposite scaffold. Those calcium ions could in turn attracted negative phosphorous ions leading to hydroxyapatite layer formation.

\section{Conclusion:}

Bioactive glass nanoparticles were successfully prepared using the quick alkali mediated sol-gel method. Also, a bioactive glass/agarose/gelatin nanocomposite scaffold was prepared for a bone engineering application. The scaffold had a well interconnected macroporous structure. It was characterized by SEM, FTIR, and TGA. The formation of a hydroxycarbonate apatite layer on the scaffold surface was confirmed by TF-XRD, FTIR and SEM/EDXA, demonstrating its potential application in bone engineering.

\section{Reference}

Balasunda G, Sato M, Webster T. JUsing hydroxyapatite nanoparticles and decreased crystallinity to promote osteoblast adhesion similar to functionalizing with RGD. Biomaterials, 27:2798, (2006).

Brinker C.J , G.W. Scherer, Sol-gel Science, Academic Press, INC, New York, (1990).

Brinker C.J, Scherer G.W The physics and chemistry of sol-gel processing.Academic Press Inc, San Diego, CA, USA, (1990).

Chiang CY., Chiou SH, Yang WE, Hsu ML, Yung MC, Tsai, ML. Chenf LK, Huang $\mathrm{HH}$ Formation of $\mathrm{TiO}_{2}$ nano-network on titanium surface increases the human cell growth. dental materials 25:10,22. .(2009)

Drury J.L., Mooney D.J., Hydrogels for tissue engineering: scaffold design variables and applications, Biomaterials 24: 4337-4351. (2003)

E. Tamjid , R. Bagheri, M. Vossoughi, A. Simchi. Effect of particle size on the in vitro bioactivity, hydrophilicity and mechanical properties of bioactive glassreinforced polycaprolactone composites. Materials Science and Engineering C31, 1526-1533(2011)

El-Kady, A.M., Ali A. F., Farag M. M., Bioactive glass/poly(L-lactide) nanocomposite scaffolds, Mater. Sci. Eng. C30,120-131. (2010)

Greenspan DC, Zhong JP, Wheeler DLBioactivity and biodegradability: Melt vs sol-gel derived Bioglass ${ }^{\circledR}$ in vitro and in vivo. In Bioceramics 11, eds. RZ LeGeros, JP LeGeros,345. (1998)

Gruber, H. E., Fisher, E. C., Jr., Desai, B., Stasky, A. A., Hoelscher, G., and Hanley, E. N., Jr.: Human intervertebral disc cells from the annulus: threedimensional culture in agarose or alginate and responsiveness to TGF-beta1. Exp. Cell. Res., 235: 13-21(1997).

Hench L L. West J K.(i) The Sol-Gel Process. Chem. Rev. 1990, 90. 33-72(ii) Biological applications of bioactive glasses.Life Chem Reports 1996; 13:187-241.(1996) 
Hench LL. Bioceramics: From concept to clinic. J. Am. Ceram. Soc, 74:87. (1991) Hye-Won Kang, Yasuhiko Tabata, Yoshito Ikada.; Fabrication of porous gelatin scaffolds for tissue engineering. Biomaterials 20:1339-41. (1999)

Izquierdo-Barba I., Salinas A. J., Vallet-Regí M., In vitro calcium phosphate layer formation on sol-gel glasses of the $\mathrm{CaO}-\mathrm{SiO} 2$ system, J Biomed Mater Res,V 47, P 243-250.(1999) .

J.A. Roether, A.R. Boccaccini, L.L. Hench, V. Maquet, S. Gautier, R. Jérôme. Development and in vitro characterisation of novel bioresorbable and bioactive composite materials based on polylactide foams and Bioglasss for tissue engineering applications. Biomaterials 23, 3871-3878,(2002)

Jen A.C., Wake C., Mikos A.G., Hydrogels for cell immobilization, Biothech. Bioeng. 50 ,357-364. (1996)

Kim Ill Y, Kawachi G, Kikuta K, Cho S B, Kamitakahara M , Ohtsuki C. Preparation of bioactive spherical particles in the $\mathrm{CaO}-\mathrm{SiO}_{2}$ system through sol-gel processing under coexistence of poly(ethylene glycol) Journal of the European Ceramic Society;28:1595,(2008)

Kokubo T, Takadama HHow useful is SBF in predicting in vivo bone bioactivity. Biomaterials; 27:2907. .(2006)

Kokubo T., Kim H.M., Kawashita M., Takadama H., Miyazaki T, Uchida M, Nakamura TNucleation and growth of apatite on amorphous phases in simulated body fluid. Glastech. Ber. Sci. Technol. 73C1:247. .,(2000)

Li J, Dou Y., Yang J., Yin Y., Zhang H, Yao F, Wang H, Yao KSurface characterization and biocompatibility of micro- and nanohydroxyapatite/chitosan-gelatin network films. Materials Science and Engineering, 29:1207. .(2009)

Marinho-Soriano E, Bourret E. Bioresour Technol 90:329-33. (2003)

Martínez-Vázquez F.J., Cabañas M.V., Paris J.L., ozanoD. L, Vallet-Regí MFabrication of novel Si-doped hydroxyapatite/gelatine scaffolds by rapid prototyping for drug delivery and bone regeneration, Acta Biomaterialia, V15, P200-209. .(2015),

Mathew Peter, Nitya Ganesh, N. Selvamurugan , S.V. Nair, T. Furuike, H. Tamura , R. Jayakumar. Preparation and characterization of chitosangelatin/nanohydroxyapatite composite scaffolds for tissue engineering applications. Carbohydrate Polymers 80: 687-694,(2010)

Puértolas J.A., Vadillo J.L, Schez-Salcedo S. , Nieto A., Ǵmez-Barrena E., Vallet-Regi MCompression behaviour of biphasic calcium phosphate and biphasic calcium phosphate-agarose scaffolds for bone regeneration. Acta Biomaterialia 7: 841-847,(2011)

Saboori A, Rabiee M, Moztarzadeh F, Sheikhi M, Tahriri M., Karimi MSynthesis, characterization and in vitro bioactivity of sol-gel-derived 
$\mathrm{SiO}_{2}-\mathrm{CaO}-\mathrm{P}_{2} \mathrm{O}_{5}-\mathrm{MgO}$ bioglass. Materials Science and Engineering $\mathrm{C}$, 29:335. . (2009)

Sánchez-Salcedo S., Nieto A., Vallet-Regí M. Hydroxyapatite/ $\beta$-tricalcium phosphate/agarose macroporous scaffolds for bone tissue engineering. Chemical Engineering Journal 137: 62-71. (2008)

Saravanapavan P., Hench LLLow temperature synthesis, structure and bioactivity of gel derived glasses in the binary $\mathrm{CaO}-\mathrm{SiO}_{2}$ system. J. Biomed Mater Res54:608. .(2001)

Sepulveda P., Jones J. R, Hench L LCharacterization of Melt-Derived 45S5 and solgel-derived 58S Bioactive Glasses. J Biomed Mater Res (Appl Biomater); 58:734. (2001)

Shapoff CA, Alexander DC, Clark AEClinical use of a bioactive glass particulate in the treatment of human osseous defects. Compendium; 18:352. .(1997)

Tang S, Yang W, Mao X. Biomed Mater 2:129-34. (2007)

Webster TJ, Ejiofor JUIncreased osteoblast adhesion on nanophase metals: Ti, Ti6Al4V, and CoCrMo. Biomaterials; 25:4731. .(2004)

Webster TJ, Ergun C, Doremus RH, Siegel RW, Bizios REnhanced osteoclast-like cell functions on nanophase ceramics. Biomaterials; 22:1327. . (2001)

Webster TJ, Smith TAIncreased osteoblast function on PLGA composites containing nanophase titania. J Biomed Mater Res A ; 74:677. (2005).

Wiseman, D. M., A. J. Domb and J. Kost Handbook of Biodegradable Polymers, Taylor \& Francis. (1998).

Xin R, Leng Y, Chen J, Zhang Q. A comparative study of calcium phosphate formation on bioceramics in vitro and in vivo. Biomaterials;26:6477. (2005)

Xin R, Leng Y., Chen J., Zhang QA comparative study of calcium phosphate formation on bioceramics in vitro and in vivo. Biomaterials; 26:6477. .(2005)

Yong K., K. Giichiro, K. Koichi, B.C. Sung, K. Masanobu, O. Chikara, J. Eur, Ceram. Soc, V28 ,P 1595. (2008)

Zhang L., WebsterT JNanotechnology and nanomaterials: Promises for improved tissue regeneration. Nano Today; 4:66. .(2009)

Zhong J., Greenspan D. C (i) Processing and Properties of Sol-Gel Bioactive Glasses. J. Biomed Mater Res (Appl Biomater) 53: 694-701. Processing and properties of sol-gel bioactive glasses. J. Biomed Mater Res Appl Biomater; 53:694. (2000) 


\section{تحضير وتوصيف متوالفات حيوية لهندة العظام أساسها الزجاج الحيوى النانومترى والأجاروز والجلآتين}

'منار مصطفى احمد, ب أ.د/علاء الدين محم إبر اهيم, أ.د/ بثينة محمد عبد الهادى, ج أ.د/أشرف فهيم

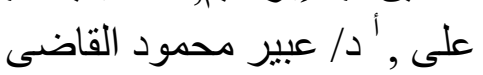

أ المركز القومى للبحوث , قسم المو اد الحيوية ,33 شارع البحوث, الدقى ,الجيزة,مصر. ب كلية علوم, جامعة عين شمس(بنات),قوم الفيزياء.

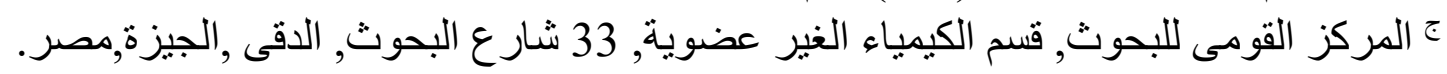

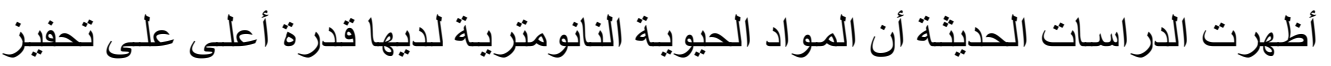

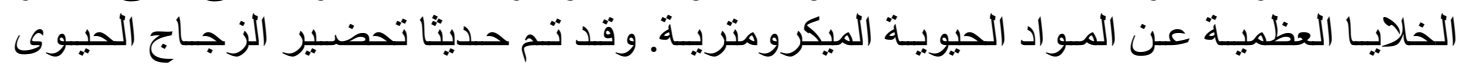

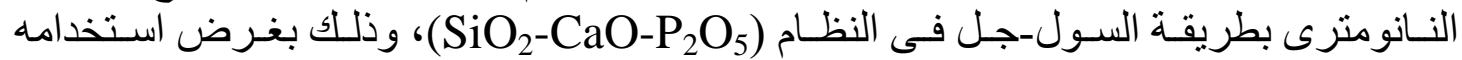

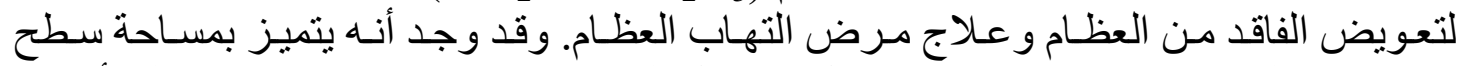

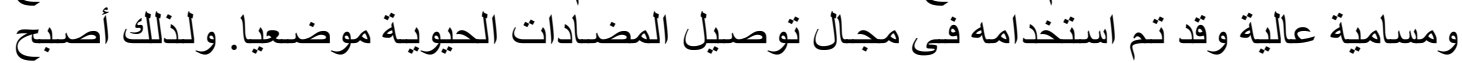

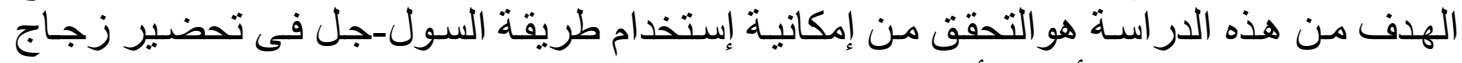

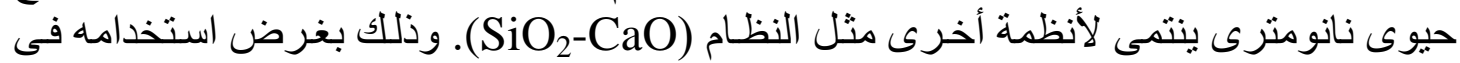

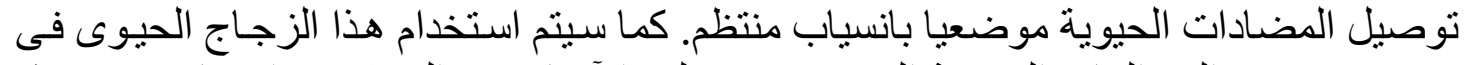

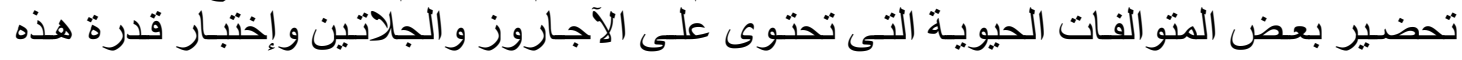

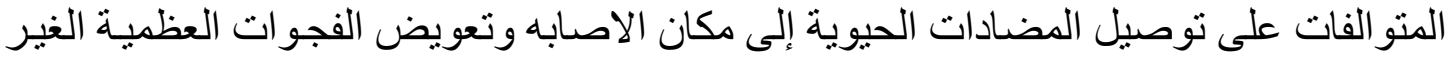

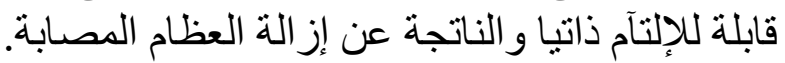

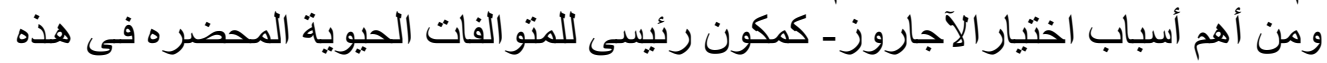

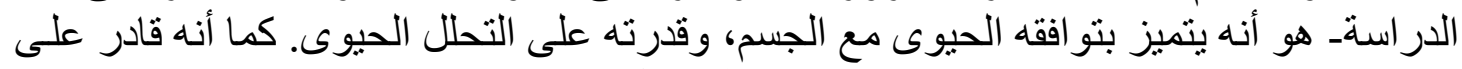

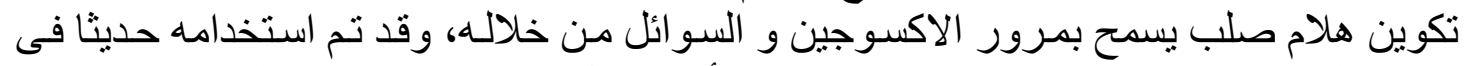

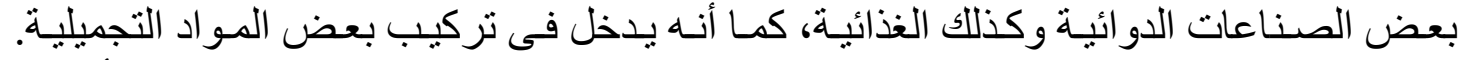

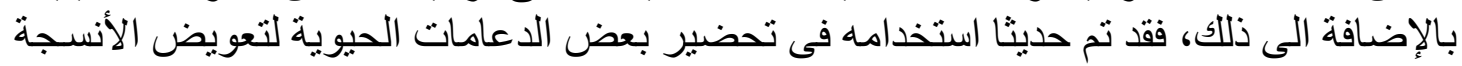

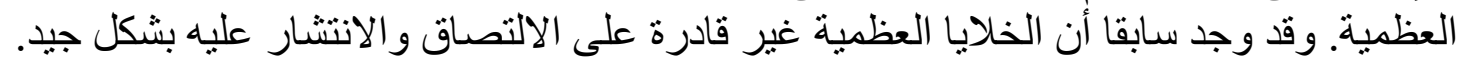

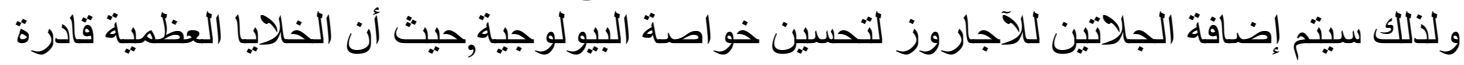

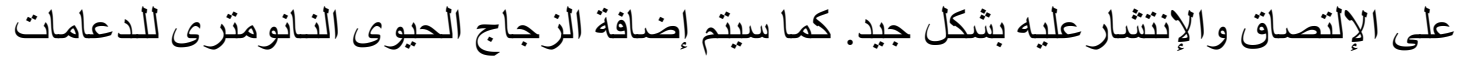

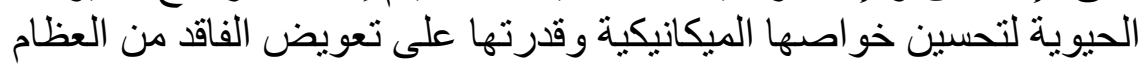

